\title{
Prevalence of mastitis in dairy goat farms in Eastern Algeria
}

\author{
Zahra Gabli ${ }^{1}$, Zouhir Djerrou ${ }^{1,2}$, Abd Elhafid Gabli ${ }^{3}$ and Mounira Bensalem ${ }^{1}$
}

1. Department of Nature and Life Sciences, Faculty of Sciences, University of August $20^{\text {th }} 1955$, Skikda, Algeria; 2. Laboratory of Pharmacology and Toxicology, University of Mentouri Constantine 1, Algeria; 3. Department of Hygiene and Animal Health, Institute of Veterinary Sciences, University of Mentouri Constantine 1, Algeria. Corresponding author: Zahra Gabli, e-mail: zahrascom@gmail.com

Co-authors: ZD: z.djerrou@univ-skikda.dz, AEG: abdelhafidgabli25@gmail.com, MB: bensalemounira@gmail.com Received: 07-02-2019, Accepted: 28-08-2019, Published online: 15-10-2019

doi: 10.14202/vetworld.2019.1563-1572 How to cite this article: Gabli Z, Djerrou Z, Gabli AE, Bensalem M (2019) Prevalence of mastitis in dairy goat farms in Eastern Algeria, Veterinary World, 12(10): 1563-1572.

\begin{abstract}
Aim: This study aimed to investigate mastitis in dairy goat farms through the California mastitis test (CMT) and bacteriological examinations.

Materials and Methods: A total of 845 goats belonging to 18 farms from four regions (Tébessa, Guelma, Souk Ahras, and Skikda) were examined.

Results: Clinical examination of the mammary glands showed that 30/845 (3.55\%) goats had clinical mastitis and 32 goats had half-teat inflammation. CMT subclinical mastitis (SCM) was detected in 815 goats that were presumed to be healthy. CMT showed 46 (5.64\%) CMT-positive goats as well as $47(2.88 \%)$ positive half-udders with a score of $\geq 2$. A total of 79 bacteria were isolated and identified from the 79 bacterial positive samples. Bacteriological analyses showed that Grampositive staphylococci were largely responsible for clinical and SCM. Coagulase-negative staphylococci, with an isolation frequency of $56.96 \%$, were the most prevalent bacteria from all isolated organisms. The second most prevalent organism was Staphylococcus aureus at $40.50 \%$ and streptococci $(2.53 \%)$ had the smallest percentage of isolation.
\end{abstract}

Conclusion: It is suggested that due to the prevalence of mastitis in this species, farmers should be aware of the problem to plan preventive and control measures to reduce dairy goat losses due to this disease.

Keywords: Algeria, bacteriological analysis, California mastitis test, dairy goats, mastitis.

\section{Introduction}

Mastitis is a general term that refers to the inflammation of mammary tissues, without regarding the cause of the inflammation [1]. It has a number of adverse health effects that affect animal welfare, agricultural economy, and food security $[2,3]$.

Mastitis is traditionally classified into clinical and subclinical divisions. Subclinical mastitis (SCM) is the most common form of mastitis, with prevalence in about $15-40 \%$ of intramammary infected dairy goats. It is a form of mastitis without the typical clinical signs of an infected mammary gland, but the pathogens still exist in the milk and colonize the mammary gland [4].

Milk produced by goats with mastitis presents a serious risk in terms of public health as it can be linked to milk-borne diseases for humans. In addition to causing hygiene and health problems, inflammation of the mammary glands can also cause economic losses due to reduced milk production, poor quality of milk, early culling of animals, and increased treatment costs $[3,5,6]$.

Copyright: Gabli, et al. Open Access. This article is distributed under the terms of the Creative Commons Attribution 4.0 International License (http://creativecommons.org/licenses/by/4.0/), which permits unrestricted use, distribution, and reproduction in any medium, provided you give appropriate credit to the original author(s) and the source, provide a link to the Creative Commons license, and indicate if changes were made. The Creative Commons Public Domain Dedication waiver (http://creativecommons.org/ publicdomain/zero/1.0/) applies to the data made available in this article, unless otherwise stated.
Mastitis is considered one of the most important diseases in domestic animals caused by multiple etiological agents. However, Staphylococcus aureus is considered to be the most common causative agent of goat mastitis, followed by a minor occurrence of mastitis by Pasteurella haemolytica, Escherichia coli, Clostridium perfringens, Streptococcus, Pseudomonas, and Nocardia genera [7].

The diagnosis of mastitis is a tedious task and can be performed using the California mastitis test (CMT) and a somatic cell count (SCC). In addition, bacteriological isolation and polymerase chain reaction identification can also be performed to confirm diagnosis [8].

Bourabah et al. [9] investigated the periodic prevalence and etiology of SCM in goats in the Tiaret region (Western Algeria). However, to the best of our knowledge, there have been no studies yet on goat mastitis in the four regions (Tébessa, Souk-Ahras, Guelma, and Skikda) of Eastern Algeria. This study aimed to determine the prevalence and the causative bacteria of mastitis in dairy goat farms in the four Eastern Algeria regions.

\section{Materials and Methods}

\section{Ethical approval}

The design of the present study was approved by the ethical committee of the Institute of Veterinary Sciences, University Mentouri Constantine 1, Algeria. 


\section{Study areas and animals}

This study was conducted on 845 Mekatia local dairy goats (142 primiparous and 703 multiparous) belonging to 18 extensive goat farms located in four regions of Northeastern Algeria. Two regions (Tébessa and Souk Ahras) are located in the steppe highlands. These regions are characterized by a semiarid climate and an altitude of more than $1200 \mathrm{~m}$. Rainfall varies from 200 to $350 \mathrm{~mm} /$ year. As a result, there is a large thermal amplitude, winter frosts range from $-2^{\circ} \mathrm{C}$ to $4^{\circ} \mathrm{C}$, and strong summer heat from $33^{\circ} \mathrm{C}$ to $38^{\circ} \mathrm{C}$. The other two regions (Guelma and Skikda) are characterized by a rainy season from October to April and a dry season from May to September. The minimum temperature is $7-15^{\circ} \mathrm{C}$ in the winter and the maximum temperature is $32-42^{\circ} \mathrm{C}$ in the summer. The altitude varies between $800 \mathrm{~m}$ and $1200 \mathrm{~m}$. These geoclimatic features are favorable for the development of goat farming. This study took place from January 2015 to March 2018 and involved goats aged 2-6 years, between the $2^{\text {nd }}$ and $6^{\text {th }}$ months of their lactation. The number of goats examined varied from 30 to 60 lactating goats per farm. The animals were free from brucellosis and were not subject to any antibiotic treatment at sampling.

\section{Clinical mastitis}

\section{Clinical examination of the udder}

A total of 845 goats were clinically examined. After a thorough visual examination, we palpated each one of the udder halves. The aim was to identify any signs of mastitis (inflammation that results in a red, hot, swollen, hard, and/or painful udder). Changes in milk color and consistency and general symptoms, such as fever, depression, and/or loss of appetite, were also assessed [10-12].

\section{SCM}

\section{Screening for SCM by CMT}

A total of 815 of 845 presumed healthy goats were collected before the morning milking and carried out from the $3^{\text {rd }}$ week of lactation to avoid interference with the colostral period [13]. The milk samples from the first jet of each quarter were put in a clean cup, and we poured the overflow to retain only about $2 \mathrm{ml}$ milk per quarter. We then added an approximately equal amount of surfactant reagents based on Teepol (sodium alkyl aryl sulfate), which induced reagents for cell membrane lysis and nuclear DNA precipitation. From this, a gel was then formed $[14,15]$. CMT was then performed and the results were assessed according to the manufacturer's recommendations (Table-1) [11]. A milk sample was microbiologically assayed when CMT value was $\geq 2$.

\section{Sampling and bacteriological examination of mastitis milk}

All inflamed halves and halves with positive CMT were sampled just before the morning milking. A volume of $10 \mathrm{ml}$ of milk from each quarter was collected in a sterile glass tube after teat disinfection
Table-1: CMT interpretation scale (David and De Cremoux, 2000).

\begin{tabular}{|c|c|c|}
\hline Appearance of the gel & Interpretation & Note \\
\hline No precipitation & Negative & 0 \\
\hline $\begin{array}{l}\text { Cloudy precipitation, which } \\
\text { disappears }\end{array}$ & Trace & 1 \\
\hline $\begin{array}{l}\text { Light persistent gel with lumpy } \\
\text { filament }\end{array}$ & Doubtful & 2 \\
\hline $\begin{array}{l}\text { Immediate thickening, "egg white" } \\
\text { type gel, detaching from the } \\
\text { bottom in filament during rotation } \\
\text { of the tray }\end{array}$ & Slightly positive & 3 \\
\hline $\begin{array}{l}\text { Curved gel, sliding in mass on } \\
\text { the bottom of the plate during its } \\
\text { rotations }\end{array}$ & Very positive & 4 \\
\hline
\end{tabular}

$\mathrm{CMT}=$ California mastitis test

with alcohol at $70^{\circ}$, washing, and removal of the first jet. The samples were labeled and immediately sent to the laboratory of the Institute of Veterinary Sciences, El Khroub, in a refrigerated cooler and placed in the refrigerator at $+4^{\circ} \mathrm{C}$. All milk samples collected from mastitis (clinical and subclinical) were subjected to bacteriological analysis in the laboratory using standard testing procedures as described in other studies [16]. Cultural bacteriology remains the reference method in the etiological diagnosis of mastitis in goats. It is a diagnosis of "certainty" highlighting the presence of a bacterium in milk. The bacteriological isolation of milk was carried out by depositing $10 \mu \mathrm{l}$ of each sample on sheep blood agar medium (5\%). After incubation for $24-48 \mathrm{~h}$ at $37^{\circ} \mathrm{C}$, the dishes were examined for the presence and appearance of bacterial colonies. Bacteria identification was performed through conventional methods (colony appearance, Gram stain, catalase test, and bound coagulase test). The biochemical characters were studied through API 20 tests (API bioMérieux, France), allowing the characterization of bacterial species within the same genus [17].

\section{Results}

\section{Clinical mastitis}

Clinical examination of the udder

Clinical examination of the mammary glands of 845 dairy goats revealed $30(3.55 \%)$ goats with clinical mastitis, of which $6 / 30(20 \%)$ were primiparous and $24 / 30(80 \%)$ were multiparous. Of the 30 goats, 28 (93.34\%) goats had only half of their udder affected, while both teats were affected in the remaining 2 goats $(6.66 \%)$. We have selected a few cases of clinical mastitis (Figures-1-3). This survey shows that out of the surveyed farms, infection was present in 16/18 farms $(88.88 \%)$, and $2 / 18$ farms $(11.11 \%, \mathrm{H}$ and $\mathrm{J})$ were free of intramammary infection (Table-2).

\section{Bacteriological examinations of clinical mastitis milk}

In this investigation, we analyzed 32 milk samples collected from 30 goats with clinical mastitis. The cultures were monobacterial with only one dominant species, whether it was an infected quarter or 


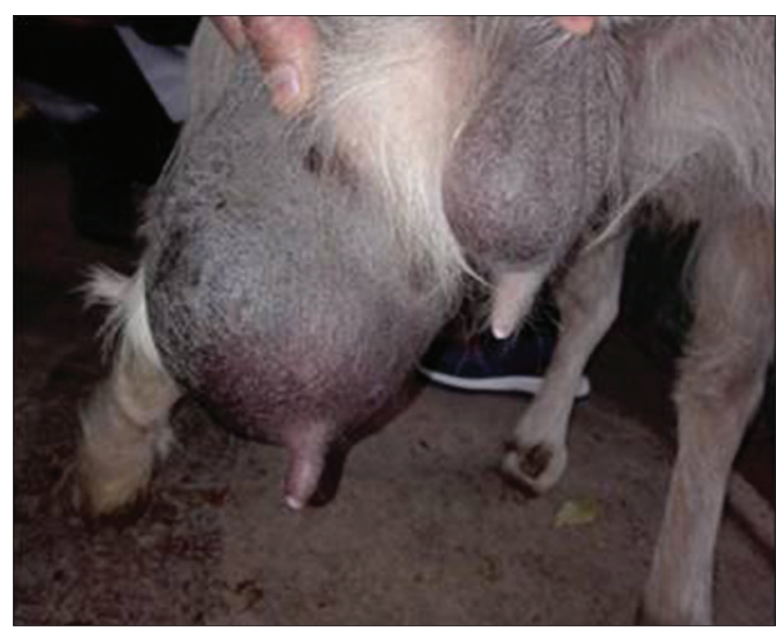

Figure-1: Asymmetry and inflammation of the udder pair in the goat.

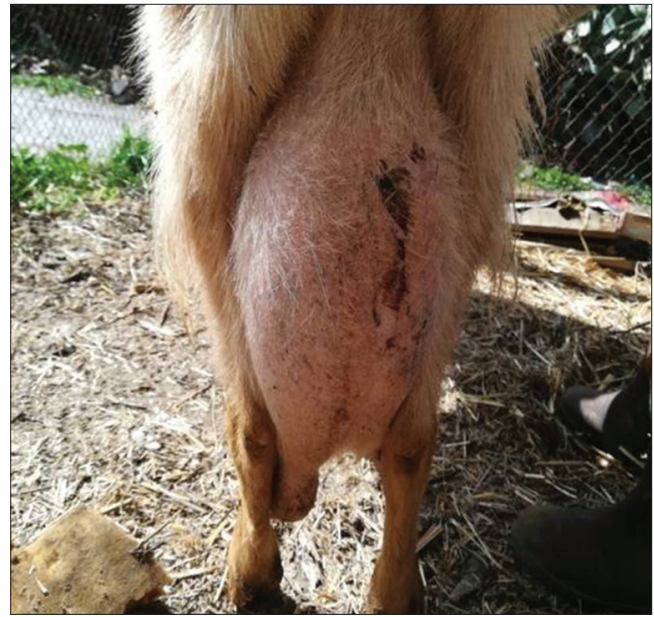

Figure-2: Infected left half-udder of the goat.

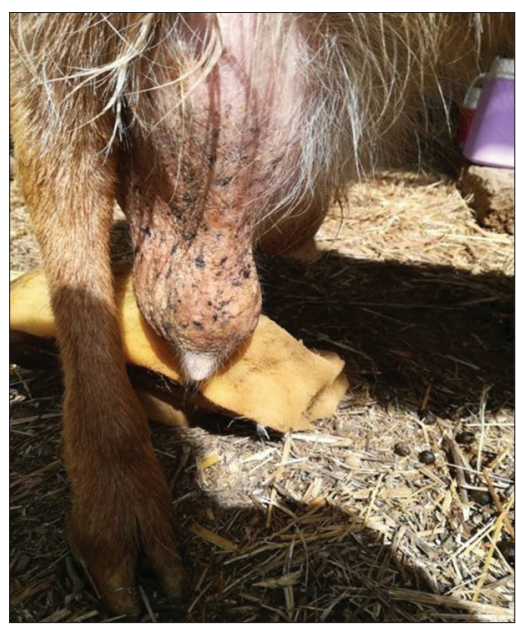

Figure-3: Infected right half-udder of the goat.

two. Thirty-two bacteria were isolated from the samples and divided into three different bacterial species.

$S$. aureus was the predominant species as it was present in 30/32 (93.75\%) of the samples. Streptococci were isolated with a frequency of $2 / 32(6.25 \%)$, of which 1/32 (3.12\%) was Streptococcus uberis and 1/32 (3.12\%) was Streptococcus agalactiae.
The distribution of isolated germs varies from one region to another. The highest number was recorded in the Tébessa region, where 11/32 (34.37\%) species were isolated. The next highest were Skikda with 8/32 (25\%), Guelma with 7/32 (21.87\%), and Souk Ahras with 6/32 (18.75\%) (Table-2). On the other hand, the level of infection varied according to the region. We recorded frequencies in descending order: Skikda with $5.71 \%(8 / 140)$, Tebessa with $4.23 \%$ (10/236), Guelma with 3.70\% (7/189), and Souk Ahras with $1.78 \%$ (5/280). Finally, the total frequency of the four regions was $3.55 \%$ (30/845), of which $6 / 213(2.81 \%)$ were primiparous and 24/632 (3.79\%) were multiparous (Table-2).

\section{SCM}

CMT test

CMT was performed on $815 / 845$ healthy presumed goats belonging to 18 farms. The results of individual CMTs revealed $46(5.64 \%)$ goats with SCM, of which 13/207 (6.28\%) were primiparous and 33/608 (5.42\%) were multiparous. In addition, 47 half-udders had CMT score of $\geq 2$ and $45 / 47$ half-udders were from one neighborhood where one udder or both quarters were affected. The level of the positivity of the test was $6.19 \%(14 / 226)$ for Tébessa, $4.36 \%$ (12/275) for Souk Ahras, 6.04\% (11/182) for Guelma, and $7.57 \%$ (9/132) for Skikda (Table-3).

\section{Bacteriological examinations of milk positive for CMT}

A total of 47 samples of milk positive for CMT showed 47 bacteria divided into eight different bacterial species with a predominance of Staphylococcus caprae at 18/47 (38.29\%), followed by Staphylococcus xylosus at 8/47 (17.02\%), Staphylococcus simulans at $7 / 47$ (14.89\%), Staphylococcus epidermidis at 5/47 (10.63\%, Staphylococcus cohnii at 4/47 (8.51\%), Staphylococcus lentus at $2 / 47(4.25 \%)$, S. aureus at $2 / 47(4.25 \%)$, and Staphylococcus hominis at $1 / 47(2.12 \%)$. Our investigation reveals the importance of coagulase-negative staphylococci (CNS) as the most dominant germs at $45 / 47(95.75 \%)$ versus $S$. aureus which was isolated at a low-frequency rate of $2 / 47(4.25 \%)$. The frequency of isolated organisms varies from one region to another: Tébessa at $29.78 \%$ (14/47), Souk Ahras at 27.65\% (13/47), Guelma at $23.40 \%(11 / 47)$, and Skikda at $19.14 \%(9 / 47)$. This bacteriological study shows that SCM exists in all farms. The distribution of different species of isolated bacteria is shown in Table-3.

\section{Distribution and frequency of bacterial species isolated from mastitis}

Only the bacteriological diagnosis was used to characterize the infections of the half-udders in this study. The results of the bacteriological analyses revealed 79 bacterial species distributed in 10 different bacterial species with a predominance of S. aureus with 32 (40.50\%) followed by Staphylococcus 


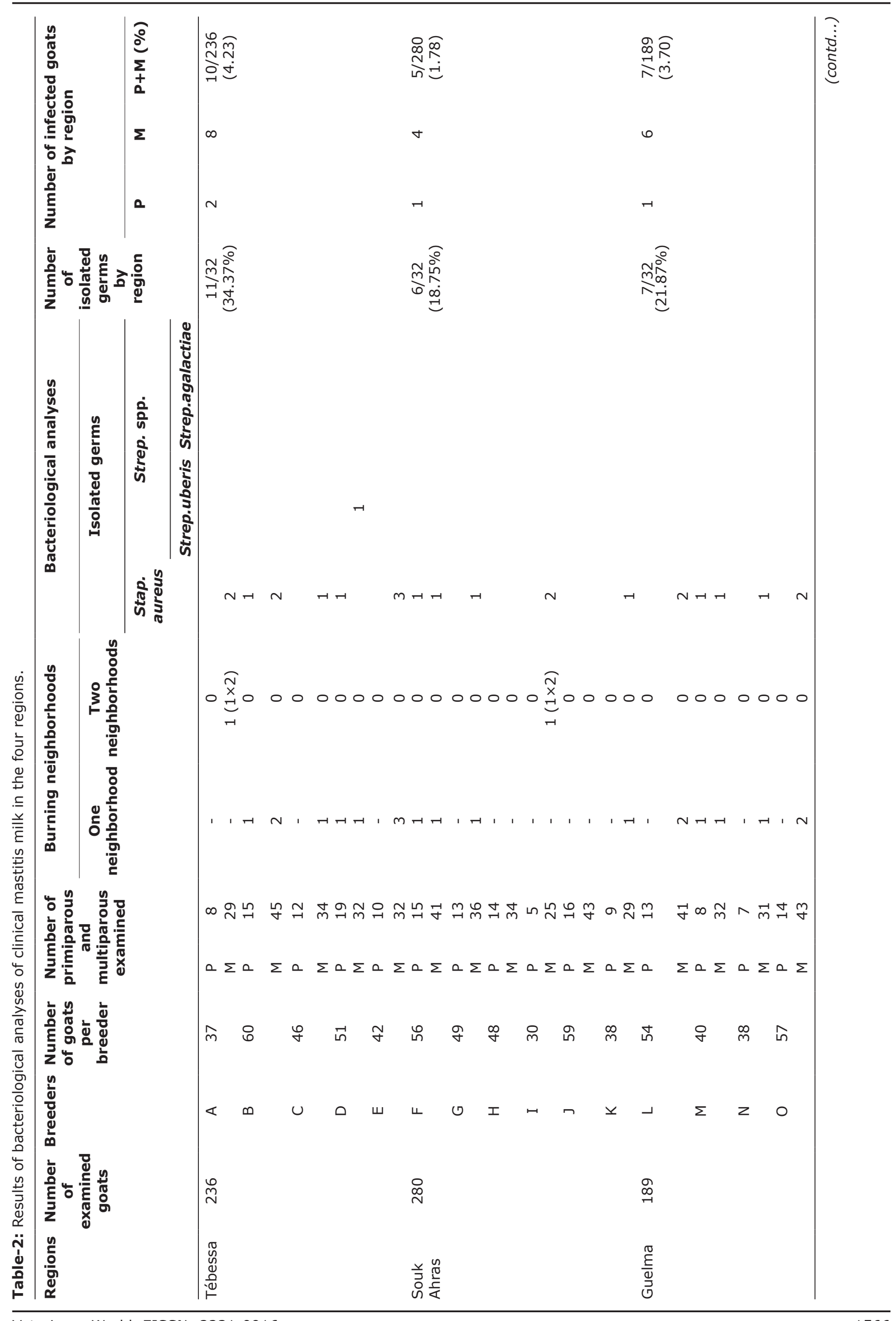




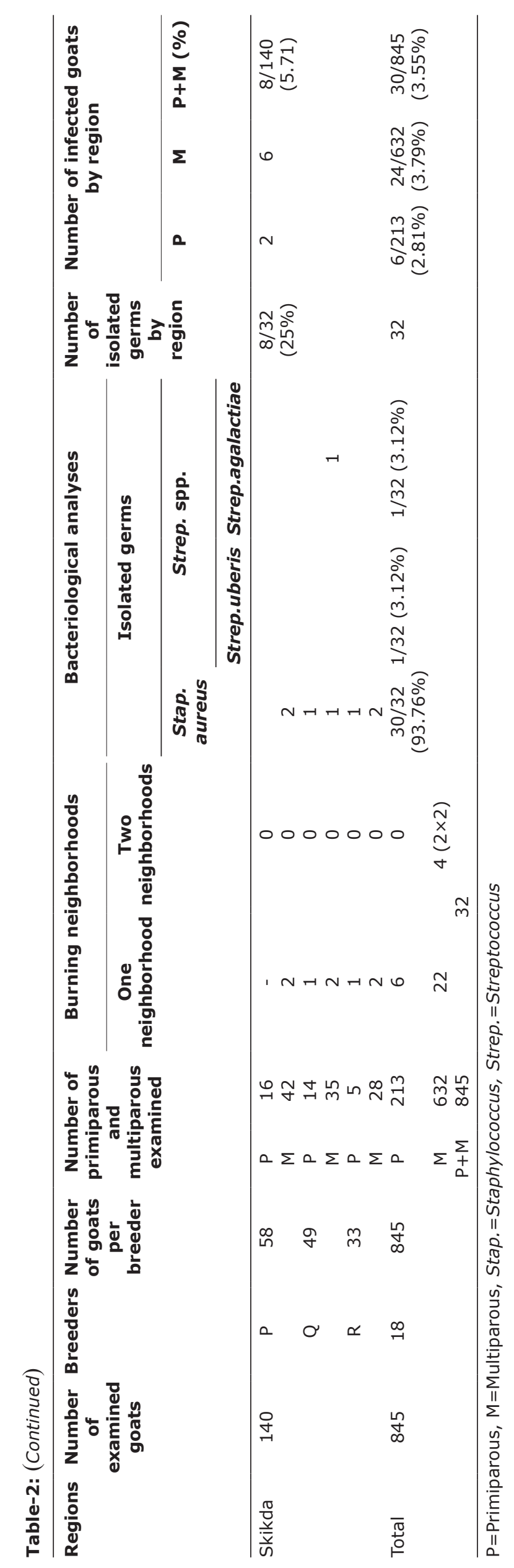

caprae with 18 (22.78\%), Staphylococcus xylosus with $8(10.12 \%)$, Staphylococcus simulans with $7(8.86 \%)$, Staphylococcus epidermidis with 5 (6.32\%), S. cohnii with $4(5.06 \%)$, S. lentus with $2(2.53 \%)$,S. hominis with 1 (1.26\%), S. uberis with 1 (1.26\%), and Streptococcus agalactiae with $1(1.26 \%)$. According to the genus, our investigation shows the importance of CNS as the most dominant bacteria at 45/47 (56.96\%) followed by $S$. aureus at $32 / 79(40.50 \%)$ and Streptococcus spp. at 2/47 (2.53\%) (Table-4). In general, S. aureus was most often isolated from clinical mastitis cases, whereas CNS were most commonly found in SCM cases. SCM dominants (CNS) and streptococci were poorly isolated from clinical mastitis and no streptococcal species were isolated from SCM samples either. Overall, the survey determined that the frequency of isolated bacteria varies from one mastitis to another and from one region to another. We recorded $39.24 \%(31 / 79)$ frequency for clinical mastitis versus $60.76 \%$ (48/79) frequency for SCM. Depending on the region, we found $31.64 \%$ (25/79) frequency for Tebessa, followed by Souk Ahras at 24.05\% (19/79), Guelma at $22.38 \%(18 / 79)$, and Skikda at $21.51 \%$ (17/79) (Table-4).

Finally, all samples from clinical mastitis and positive CMT gave positive results in bacteriological examinations.

\section{Discussion}

Clinical examination of udders showed that dairy goats of various ages (primiparous and multiparous) were susceptible to mastitis. Applying CMT to healthy udder halves revealed the presence of SCM in primiparous and multiparous goats.

Bacteriological examinations revealed the characteristics of the etiology of clinical mastitis, where $S$. aureus was the most commonly isolated bacteria from the udder $(40.50 \%)$ and streptococci $(6.25 \%)$ were the least isolated. This result is consistent with the majority of studies that report that, unlike bovine mastitis, streptococci are very rarely the cause of mammary infections in goats [18-25].

SCM is difficult to detect with milk and udders that appear healthy. However, it can be suspected if there is a decrease in milk production [26]. SCM can then be revealed using a CMT test or Teepol test. This test has been used for more than 40 years in several countries [27] and remains the most used and successful test in dairy cows for detecting SCM $[3,28,29]$. It gives a qualitative answer on the status of each quarter of the udder (healthy or infected) and makes it possible to select which animals to sample from during study on mastitis [30,31]. It has the advantage of being inexpensive and providing an immediate response [32].

Regarding SCM in the current study, CNS were the most commonly isolated bacteria in seemingly normal goats $(95.75 \%)$ and $S$. aureus was the second most common (4.25\%). Similar results have been reported in other studies: Lerondelle and Poutrel 


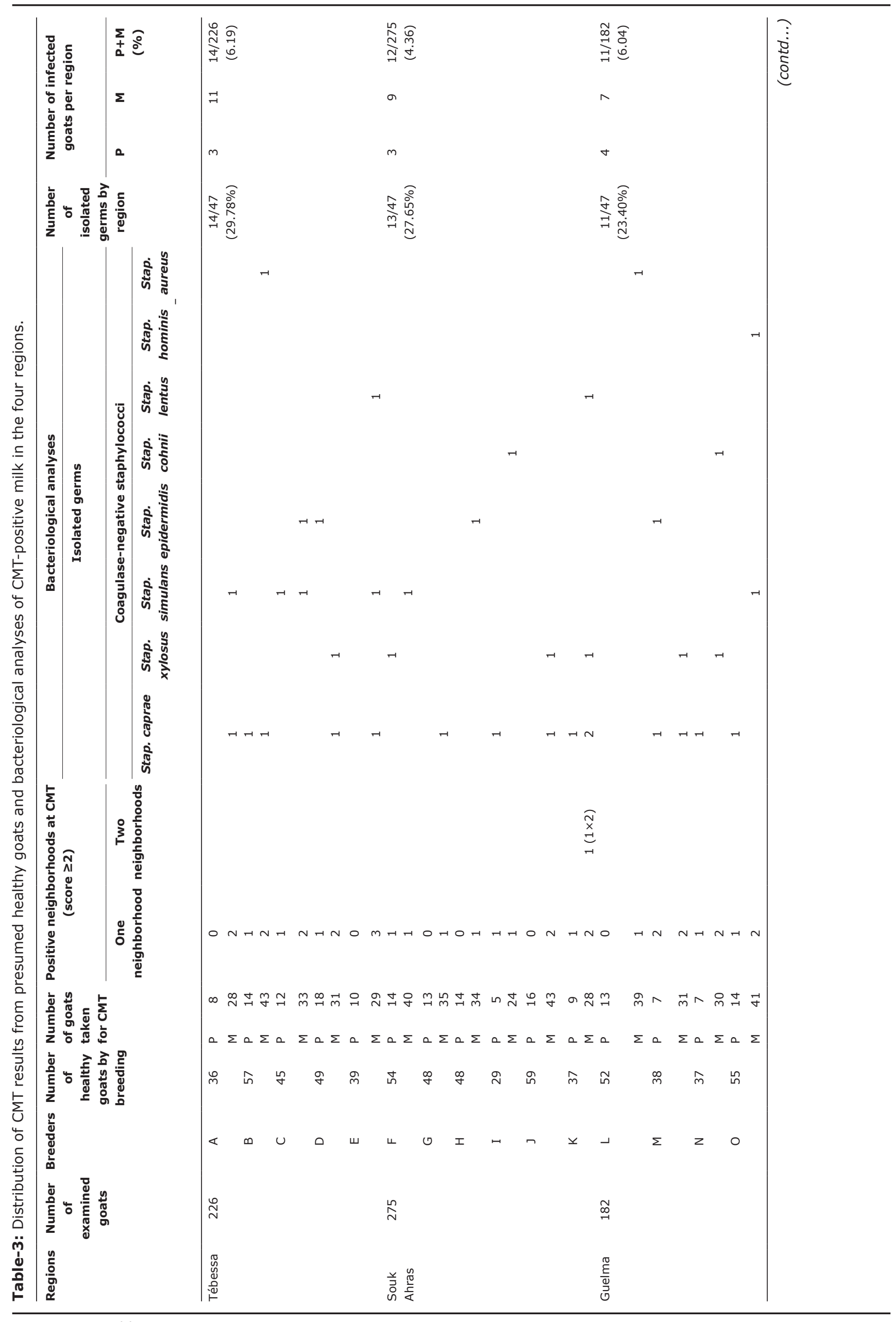




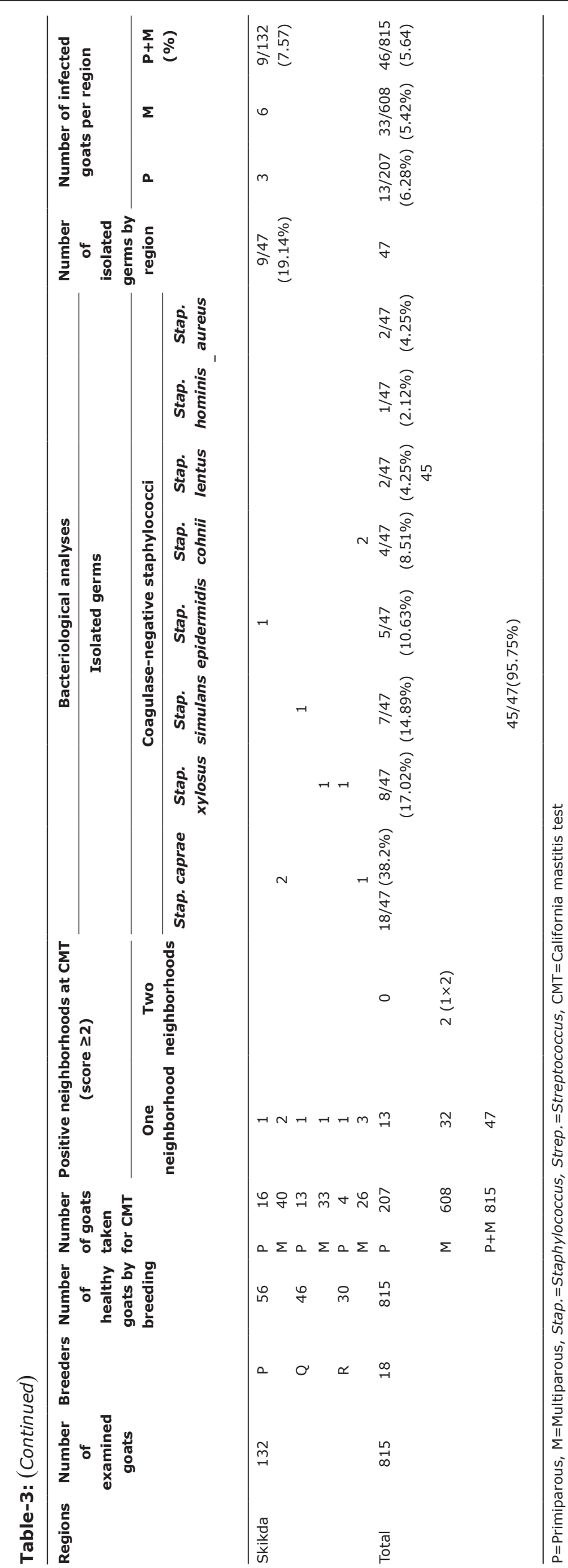




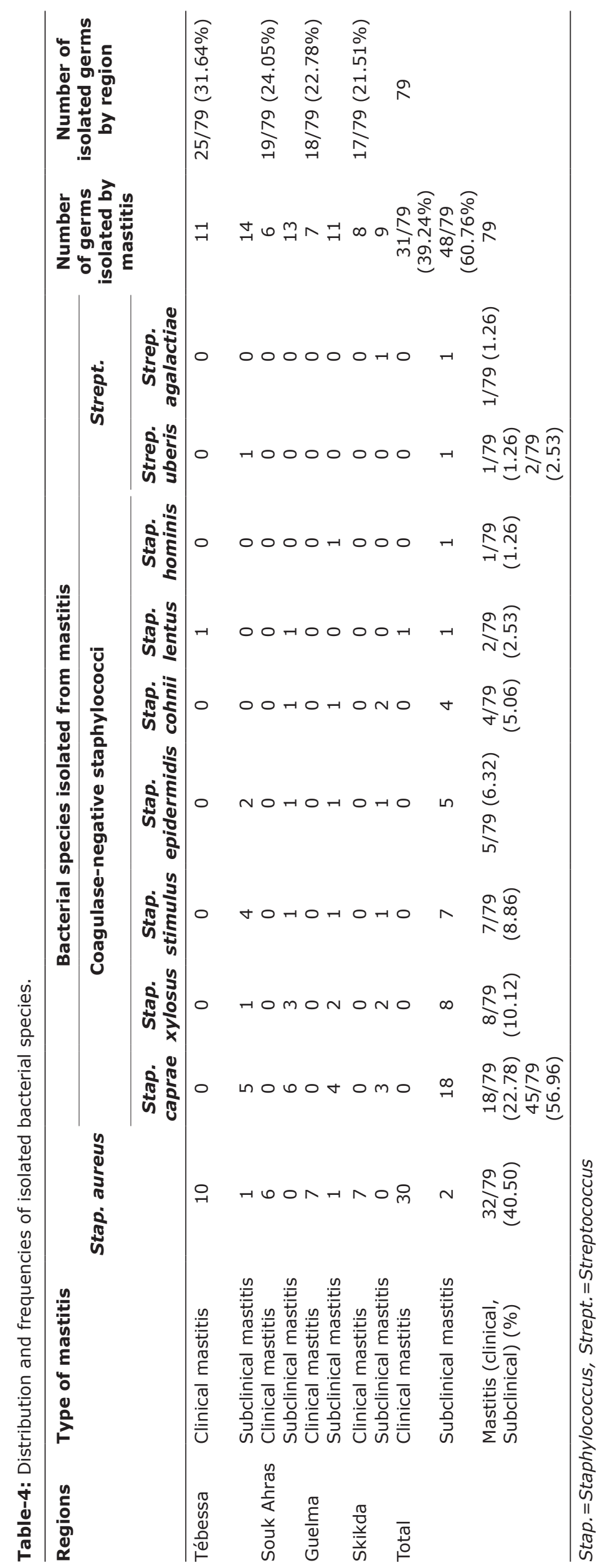


found $76.24 \%$ for CNS versus $17.8 \%$ for $S$. aureus. E1 Idrissi recorded $42.9 \%$ for CNS and $13 \%$ for S. aureus, while Ferrer showed $53.2 \%$ for CNS and $13.5 \%$ for $S$. aureus, and Contreras identified $30.3 \%$ for CNS as well, while Bergonnier isolated $60-90 \%$ of CNS [21, 26,32-34].

In contrast to our results, Enterobacteriaceae, Pseudomonas, Corynebacteria, Bacillus, Mycoplasma, and Erysipelothrix have been isolated in several studies $[19,20,25,32]$. Regarding the lack of isolation of enterobacteria in our investigation that may have been related to the physiological and anatomical character of the goat: The droppings of goats are hard and dry which reduces the contamination of the udder, by fecal germs, in this species [33]. In addition, the teat canal is smaller, and therefore, contamination from the environment is more difficult.

Overall, staphylococci mammary infection in goats is due to the presence of these commensal germs of the mammary integument [34-39]. Therefore, contamination usually occurs during milking operations and not from the environment. Other studies have confirmed the significance of staphylococcal strain present in the etiology of SCM in sheep and cows [40-43].

Finally, the higher prevalence of intramammary infection with $S$. aureus can cause a public health problem in food safety.

This variation in the prevalence of mastitis (clinical and subclinical) could be attributed to the definition of infection, which is variable from one author to another [44], and to the use of different diagnostic methods (CMT and bacteriological examination SCCs). In sheep, the majority of authors propose a point threshold allowing the best "instant" discrimination between "healthy" and "infected" udders or half-udders. The study of Bergonier et al. (1994) provides a dynamic model describing whole lactations, where the best decision rule was as follows: A half-udder is "healthy" if all its SCCs except one are $<500 *$ $10^{3} \phi / \mathrm{mL}$, "infected" if $<3$ SCC are $>1000 * 10^{3} \phi / \mathrm{mL}$, and "doubtful" in all other cases. The overall value of this rule is $79.2 \%$ [45]. Bourabah et al. reported that the high percentage of the SCM could be due to a lack of hygiene and to the practice of traditional breeding of extensive type, which favors diseases [9].

\section{Conclusion}

The present study, conducted on multiple dairy goat farms, has shown the prevalence of clinical mastitis with an average infection level of $40.50 \%$ versus $59.49 \%$ for SCM. It is not possible to avoid mastitis completely. However, we suggest that to reduce the incidence of mastitis in dairy goat farms in the study areas, it is essential to present the information to farmers on the causes, the economic and health consequences, as well as the control of mastitis should imply the clinical examination of the udder, and a systematic and early screening of these latent affections through a quick and reliable test, such as CMT. As well as, a bacteriological examination should be performed to identify the pathogens responsible for these infections to limit the transmission of infections and propose treatment or, if necessary, reform.

\section{Authors' Contributions}

ZG designed and carried out the research study along with AEG. ZD and MB helped with the design and correction of the manuscript. All authors read and approved the final manuscript.

\section{Acknowledgments}

All authors are thankful to the staff of farms from the four studied regions (Tébessa, Guelma, Souk Ahras, and Skikda) for their help in the collection of samples. The authors did not receive financial assistance for this study from any source.

\section{Competing Interests} interests.

The authors declare that they have no competing

\section{Publisher's Note}

Veterinary World remains neutral with regard to jurisdictional claims in published institutional affiliation.

\section{References}

1. Rashid, M., Saleem, M.I., Deeba, F., Khan, M.S., Mahfooz, S.A., Ali butt, A. and Abbas, M.W. (2017) Effect of season on occurrence of caprine mastitis in Beetal in Faisalabad premises. Matrix Sci. Med., 1(1): 19-21.

2. Dore, S., Liciardi, M., Amatiste, S., Bergagna, S., Bolzonid, G., Caligiuri, V., Cerrone, A., Farina, G., Montagna, C.O., Saletti, M.A., Scatassa, M.L., Sotgiu, G. and Cannas, E.A. (2016) Survey on small ruminant bacterial mastitis in Italy, 2013-2014. Small Rumin. Res., 141: 91-93.

3. Hristov, K., Popova, T., Pepovich, R. and Nikolov, B. (2016) Characterization of microbial causative agents of subclinical mastitis in goats in Bulgaria. Int. J. Curr. Microbiol. Appl. Sci., 5(8): 316-323.

4. Omar, S. and Mat-Kamir, N.F. (2018) Isolation and identification of common bacteria causing subclinical mastitis in dairy goats. Int. Food Res. J., 25(4): 1668-1674

5. Gelasakis, A.I., Mavrogianni, V.S., Petridis, I.G., Vasileiou, N.G.C. and Fthenakis, G.C. (2015) Mastitis in sheep for the last 10 years and the future of research. Vet. Microbiol., 181(1-2): 136-146

6. Pleguezuelos, F.J., De La Fuente, L.F. and Gonzalo, C. (2015) Variation in milk yield, contents and incomes according to somatic cell count in a large dairy goat population. J. Adv. Dairy Res., 3(145): 1-6.

7. Olechnowicz, J. and Jaśkowski, J.M. (2014) Mastitis in small ruminants. Med. Weter, 70(2): 67-72.

8. Paterna, A., Contreras, A., Gómez-Martín, A., Amores, J., Tatay-Dualde, J., Prats-van der Ham, M. and De la Fe, C. (2014) The diagnosis of mastitis and contagious agalactia in dairy goats. Small Rumin. Res., 121(1): 36-41.

9. Bourabah, A., Ayad, A., Boukraa, L., Hammoudi, S.M. and Benbarek, H. (2013) Prevalence and etiology of subclinical mastitis in goats of the Tiaret Region, Algeria. Glob. Vet., 11(5): 604-608.

10. Matthews, J. (1999) Diseases of the Goat. $2^{\text {nd }}$ ed. Blackwell Science, Oxford. p266.

11. David, V. and De Cremoux, R. (2000) Palpation and 
observation of the udder. Réussir Chèvre, 237: 27-29.

12. Contreras, A., Luengo, C., Sanchez, A. and Corrales, J.C. (2003) The role of intramammary pathogens in dairy goats. Livest. Prod. Sci., 79(2-3): 273-283.

13. Maisi, P. (1990) Analysis of physiological changes in caprine milk with CMT, NAGase and antitrypsin. Small Rumin. Res., 3(1): 485-492.

14. Montaldo, H. and Martinez-Lozano, F.J. (1993) Phenotypic relationship between udder and milking characteristics, milk production and California mastitis test in goats. Small Rumin. Res., 12(3): 329-337.

15. Paape, M.J., Poutrel, B., Capuco, A.V., Contreras, A. and Marco, J.C. (2001) Milk somatic cells and lactation in small ruminants. J. Dairy Sci., 84(E. Suppl): E237-E244.

16. Tariba, B., Kostelić, A., Šalamon, D., Roić, B., Benić, M., Babić, N.P. and Salajpa, K. (2017) Subclinical mastitis and clinical arthritis in French Alpine goats serologically positive for caprine arthritis-encephalitis virus. Vet. Arhiv., 87(2): 121-128.

17. Carter, G.R. (1985) Diagnostic Procedures in Veterinary Bacteriology and Mycology. $4^{\text {th }}$ ed. Springfield, Charles C. Thomas, Illinois.

18. Ajayi, S.A., Shuaibu, Y., Aud, F.D., Asagba, M.A. and Lamorde, A.G. (1987) Sheep and goat production in Nigeria. In: Nigeria Livestock Farmer. ABU Press Ltd., Samaru-Zaria. p18-21.

19. Kalogridou, D.V. (1991) Mastitis related pathogens in goat milk. Small Rumin. Res., 4(2): 203-211.

20. El Idrissi, A.H., Benkirane, A. and Zardoune, M. (1994) Investigation of subclinical mastitis in dairy goat farming in Morocco. Rev. Elev. Méd. Vét. Pays Trop., 47(3): 285-287.

21. Bergonnier, D., Blanc, M.C., Fleury, B., Lagriffoul, G., Barillet, F. and Berthelot, X. (1997) Les mammites des ovins et des caprins laitiers: Étiologie, épidémiologie et contrôle. Renc. Rech. Rum., 4(1): 251-260.

22. White, E.C. and Hinckley, L.S. (1999) Prevalence of mastitis pathogens in goat milk. Small Rumin. Res., 33(2): 117-121.

23. Ameh, J.A. and Tari, I.S. (2000) Observations on the prevalence of caprine mastitis in relation to predisposing factors in Maiduguri (Nigeria). Small Rumin. Res., 35(1): 1-5.

24. Bergonier, D., De Cremoux, R., Lagriffoul, G., Rupp, R. and Berthelot, X. (2002) Etiology and epidemiology of mastitis. Le Point Vét., (33): 40-45.

25. Ferrouillet, C. and Bergonier, D. (2003) Les mammites subcliniques chez la chèvre laitière. Méd. Vét. Québec, 33(1-2): 16-20.

26. Contreras, A., Sierra, D., Corrales, J.C., Sanchez, A. and Marco, J. (1996) Physiological threshold of somatic cell count and California mastitis test for diagnosis of caprine subclinical mastitis. Small Rumin. Res., 21(3): 259-264.

27. Contreras, A., Paape, M.J. and Miller, R.H.(1999) Prevalence of subclinical infection caused by Staphylococcus epidermidis in a commercial dairy goat herd. Small Rumin. Res., 31(3): 203-208.

28. Ruegg, P.L. and Reiman, D.J. (2002) Milk quality and mastitis tests. Bov. Pract., 36(1): 41-54.

29. Gonzales, R.N., Jasper, D.E., Farver, T.B., Bushnell, R.B. and Franti, C.E. (1988) Prevalence of udder infections and mastitis in 50 California dairy herds. J. Am. Med. Assoc., 193(3): 323-328.

30. Ryan, D. and Greenwood, P.L. (1990) Prevalence of udder bacteria of milk samples from four dairy goats herds. Aust. Vet. J., 67(10): 362-363.

31. Busato, A., Trachsel, P., Schallibaum, M. and Blum, J.W. (2000) Udder health and risk factors for subclinical mastitis in organic dairy farms in Switzerland. Prev. Vet. Med., 44(3-4): 205-220.

32. Cocchi, M., Deotto, S., De Zan, G., Zandonà, L. and Moro, N. (2018) Septicaemic spread and mastitis due to Erysipelothrix rhusiopathiae in a goat. J. Comp. Pathol., 166: 136

33. Suguna, M., Bhat, R. and Wan Nadiah, W.A. (2012) Microbiological quality evaluation of goat milk collected from small scale dairy farms in Penang Island, Malaysia. Int. Food Res. J., 19(3): 1241-1245.

34. Hinckley, B.S., Post, J.E. and Duval, M.C. (1985) The role of nonhemolytic staphylococci in caprine mastitis. Vet. Med., 80: 76-80.

35. Verkade, E. and Kluytmans, J. (2014) Livestock-associated Staphylococcus aureus CC398: Animal reservoirs and human infections. Infect. Genet. Evol., 21: 523-530.

36. Zhao, Y., Liu, H., Zao, X., Gao, Y., Zhang, M. and Chen D. (2015) Prevalence and pathogens of subclinical mastitis in dairy goats in China. Trop. Anim. Health Prod., 47(2): 429-435.

37. Kumar, R., Gupta, D.K., Bansal, B.K., Singh, S., Sharma, S., Kumar, A. and Uppal, S.K. (2016) Prevalence, current antibiogram and risk factors associated with mastitis in dairy goats in Punjab. Int. J. Sci. Environ. Tech., 5(6): 4580-4593.

38. Yahia, A., Mrezgui, D., Hamrat K. and Kaidi, R. (2016) Prevalence of subclinical mastitis in the local goats in the province of Laghouat (Algeria). Bull. UASVM Vet. Med., 73(2): 12169.

39. Mugabe, W., Nsoso, S.J., Mphapho, G.S., Kamau, J.M., Mahabile, W., Shah, A.A., Nazar, M., Khan, I.U., Kaka, N.A. and Shah, I.A. (2017) Occurrence of caprine mastitis and its etiological agents and associated selected risk in mild lactating goats in the Oodi extension area of Kgatleg district, Botswana. Acad. Web J. Agric. Res., 2(1): 14-20.

40. Vanderhaeghen, W., Piepers, S., Leroy, F., Van Coillie, E., Haesebrouck, F. and De Vliegher, S. (2015) Identification, typing, ecology and epidemiology of coagulase-negative staphylococci associated with ruminants. Vet. J., 203(1): 44-51.

41. Akkou, M., Antri, K., Bachtarzi, M.A., Bes, M., Tristan, A., Dauwalder, O., Kaidi, R., Meugnier, H., Tazir, M., Etienne, J., Laurent, F. and Ramdani-Bouguessa, N. (2016) Phenotypic and genotypic characterization of Staphylococcus aureus strains associated with bovine mastitis and nasal carriage of workers in contact to animals in Algeria. Pak. Vet. J., 36(2): 184-188.

42. Rainard, P., Foucras, G., Fitzgerald, J.R., Watts, J.L., Koop, G. and Middleton, J.R. (2018) Knowledge gaps and research priorities in Staphylococcus aureus mastitis control. Transbound. Emerg. Dis., 65(Suppl 1): 149-165.

43. Vasileiou, N.G.C., Chatzopoulos, D.C., Gougoulis, D.A., Sarrou, S., Katsafadou, A.I., Spyrou, V., Mavrogianni, V.S., Petinaki, E. and Fthenakis, G.C. (2018) Slime-producing staphylococci as causal agents of subclinical mastitis in sheep. Vet. Microbiol., 224: 93-99.

44. Bergonier, D. and Berthelot, X. (1993) Mastitis and milk quality in small ruminants. Point Vét., 25(155): 472-475.

45. Bergonier, D., Van De Wiele, A., Arranz, J.M., Barillet, F., Lagriffoul, G., Concordet, D. and Berthelot, X. (1994) Détection des Infections Mammaires Subcliniques Chez la Brebis Laitière à L'aide des Comptages de Cellules Somatiques: Propositions de Seuils Physiologiques. Proceedings of the International Symposium Somatic Cell Counts and Milk of Small Ruminants, Bella $25-27^{\text {th }}$ September, Italy. 